\title{
EFISIENSI ENERGI PADA JARINGAN SELULER DENGAN TEKNIK BASE-STATION SLEEP-MODE: STUDI LITERATUR
}

\author{
Sayekti Harits Suryawan ${ }^{1)}$, Mohammad Al Hafidz ${ }^{2)}$, Deny Hermansyah ${ }^{3)}$, \\ Heri Supriyanto ${ }^{4)}$, Yanuandika Akbar ${ }^{5)}$ \\ 1,23,4,5) Magister Sistem Informasi, Fakultas Teknologi Informasi, Institut Teknologi Sepuluh Nopember \\ Sukolilo, Surabaya, 60111 \\ E-Mail: sayekti.harits@gmail.com ${ }^{1)}$; hafidz1299@gmail.com ${ }^{2)}$; d3n1.h29@gmail.com ${ }^{3)}$; \\ herisupriyanto3@gmail.com ${ }^{4)}$; yanuandika.akbar@gmail.com ${ }^{5}$;
}

\begin{abstract}
ABSTRAK
Penggunaan Teknologi Komunikasi pada dekade ini menunjukkan peningkatan trafik data yang sangat signifikan. Dalam hal ini, operator jaringan seluler melakukan inovasi untuk mengurangi jumlah penggunaan energi yang ditimbulkan dari banyaknya jumlah energi yang digunakan tanpa mengurangi quality of service (QoS) kepada costumer. Tujuan pemanfaatan penggunaan energi ini supaya operator jaringan lebih efisien dan tidak mengurangi tingkat efektifitas dalam pemakaian energi yang dikeluarkan. Paper ini menjelaskan mengenai pemakaian jaringan dengan teknologi teknik Base-Station Sleep-Mode. Metode ini akan menjalankan auto control untuk menjalankan fungsinya pada pemancar jaringan, sehingga dibutuhkan sebuah pendekatan untuk memproses dengan menggunakan parameter-parameter yang dibutuhkan diantaranya User Association, SON (Self-Organizing Network), Cell Zooming, Traffic Prediction, dan Heterogenous Deployment. Salah satu hasil penelitian dari BS Sleeping mode menunjukkan hasil yaitu didapatkan nilai efisiensi energi hingga $90 \%$ pada akhir pekan di area bisnis dan perkantoran, dan $30-40 \%$.
\end{abstract}

Kata Kunci : Jaringan Seluler, Quality of Service, Base-Station Sleep-Mode.

\section{PENDAhuluan}

Dalam beberapa dekade terakhir, komunikasi pada mobile network menunjukkan peningkatan pada trafik data yang sangat signifikan sehingga menyebabkan tingginya konsumsi energi untuk memenuhi kebutuhan trafik data tersebut [1]. Peningkatan penggunaan energi tersebut juga berdampak kepada peningkatan jumlah polusi $\mathrm{CO} 2$ dari pembangkit listrik dan juga meningkatkan tagihan listrik kepada operator. Hal ini mendorong peneliti dan operator jaringan seluler untuk melakukan inovasi dalam mengurangi jumlah penggunaan energi dan dampak yang ditimbulkan dari banyaknya jumlah energi yang digunakan tanpa mengurangi Quality of Service (QoS).

Dalam suatu penelitian [15] berdasarkan jejak dari trafik temporal sebenarnya selama satu miggu, dilaporkan bahwa BS pada umumnya kurang dimanfaatkan dengan baik dengan dibawah $10 \%$ dari puncaknya pada saat trafik sedang rendah dan $30 \%-45 \%$ pada hari kerja dan akhir pekan. akan tetapi BS yang memiliki aktifitas kecil maupun tanpa aktifitas memakan $90 \%$ dari energi puncak. Dalam mengurangi jumlah konsumsi energi pada jaringan seluler lima kategori pendekatan yang telah diklasifikasikan pada penelitian-penelitan sebelumnya, antara lain: meningkatkan efisiensi energi pada komponen hardware, mematikan beberapa komponen secara selektif, optimasi pada efisiensi energi pada proses transmisi radio, merencanakan dan mengimplementasikan heterogenous cell, mengadopsi penggunaan energi terbarukan [2].

Pada jaringan seluler yang ada, Base-Station (BS) selalu menyala meskipun perbedaan dalam dalam penggunaan trafik dari lokasi satu dengan yang lain dan dari waktu ke waktu memiliki perbedaan yag fluktuatif sehigga hal seperti ini sangat membuang energi [3]. BS sleeping strategy merupakan salah satu solusi yang menjanjikan dalam mengurangi penggunaan energi dan dampak polusi yang terjadi karena penggunaan energi tersebut, sebagai contoh dengan melakukan basic on/off switching pada BS yang memiliki load rendah dan mengalihkan layanan ke BS terdekat untuk menjaga QoS minimum yang harus dipenuhi [1] . Dengan cara mengaktifkan sleep mode pada BS, maka BS akan menjadi nonaktif dan hanya menggunakan energi yang sangat kecil untuk mendukung aktivasi jarak jauh jika dibutuhkan dalam memenuhi QoS minimal [4].

Tingkat efisiensi energi yang dapat diraih pada teknik BS sleep-mode bervariasi berdasarkan metode yang digunakan dan faktor-faktor lain yang memungkinkan penggunaan teknik ini. Maka dalam paper yang ini, kami ingin menyajikan tingkat efisiensi optimal yang dapat dicapai dengan teknik BS Sleep mode pada jaringan seluler berdasarkan hasil penelitian yang ada sebelumnya. 


\section{TINJAUAN PUSTAKA}

\subsection{Jaringan Seluler}

Jaringan Seluler (cellular network) atau yang biasa dipanggil mobile Networks merupakan jaringan radio terdistribusi yang melewati area-area yang disebut sel, dimana tiap sel melayani minimal satu transceiver yang biasa diketahui sebagai cell site ataupun base station. Pada jaringan seluler tiap sel menggunakan set frekuensi yang saling berbeda dengan sel tetangganya, hal ini berfungsi untuk menghindari adanya interferensi dan menyediakan bandwidth yang terjamin untuk tiap sel. Ketika selsel yang saling bertetanggaan satu sama lain ini digabungkan, maka mereka hal ini akan membuat adanya cakupan wilayah radio yang lebih luas secara geografis. Hal inilah yang membuat transceiver-transceiver portabel seperti ponsel, pager, dan alat komunikasi seluler lainnya dapat berkomunikasi antar satu sama lain, dan juga dengan transceiver tetap seperti telepon rumah yang berada pada jaringan tersebut.

\subsection{Green Networking}

Kebutuhan akan infrastruktur teknologi informasi dan komunikasi (TIK) yang meningkat dan berkembang pesat mengakibatkan kebutuhan energi untuk operasional infrastruktur tersebut meningkat dan berakibat langsung pada krisis energi dan bertambahnya emisi gas rumah kaca yang dapat memicu global warming dan bahaya lingkungan lainnya. Oleh karena itu kalangan industri, pemerintah dan akademisi melakukan riset bersama untuk menghasilkan teknik serta strategi untuk membangun infrastruktur TIK yang ramah lingkungan dan efisien dalam penggunaan energi (Green Technology).

Teknik dan strategi ini berkaitan erat dengan adanya trade-off antara konsumsi energi dan performa, seperti QoS, throughput, skalabilitas dan lainnya. Beberapa cara untuk mengurangi konsumsi energi pada celluler network dibagi menjadi beberapa hal yaitu sebagai berikut: mengurangi konsumsi energi Base Station, mengurangi jumlah site Base Station, menggunakan sumber energi yang bisa diperbaharui, dengan mematikan Base Station/Transceivers, menggunakan skema multi antena [5]. Selain mengurangi konsumsi energi, green cellular network bagi operator seluler secara ekonomi dapat mengurangi pembiayaan listrik untuk BS.

Green networking adalah praktik pemilihan teknologi jaringan hemat energi dan produk, dan meminimalkan penggunaan sumber daya bila memungkinkan [6].

\subsection{Teknik Base-Stations Sleep-Mode}

Sleep mode adalah mode daya rendah untuk perangkat elektronik seperti seluler, komputer, televisi, dan perangkat dikendalikan remote. Mode ini menyimpan secara signifikan konsumsi energy dibandingkan dengan mematikan perangkat kemudian menghidupkan kembali. Mode ini memungkinkan pengguna untuk menghindari intruksi ulang atau perangkat melakukan reboot. Banyak perangkat menandakan mode daya ini dengan lampu daya LED berwarna berdenyut atau merah.

Base station merupakan sebuah transceiver yang menghubungkan sejumlah perangkat dengan perangkat lainnya untuk berkomunikasi satu sama lain dan/atau daerah yang lebih luas. Pada jaringan seluler menyediakan koneksi antara ponsel dan jaringan telepon yang lebih luas. Dalam sebuah jaringan komputer itu adalah transceiver bertindak sebagai router untuk komputer dalam jaringan, mungkin menghubungkan mereka ke jaringan area lokal dan / atau internet.

\subsection{Metodelogi}

Pada bagian ini menjelaskan tentang metode yang digunakan dalam penulisan paper ini. Metode penulisan paper ini terdiri atas: (1) menformulasikan permasalahan, (2) mengumpulkan paper, (3) melakukan pengulasan paper, hingga (4) melakukan analisis dan menginterpretasikan paper. Pada gambar 1 merupakan alur proses atau tahapan tahapan yang akan dilakukan dalam penulisan paper ini.

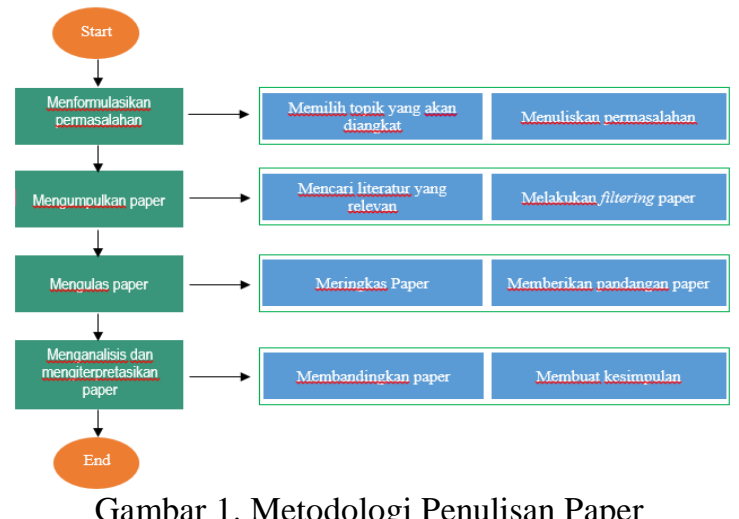

Dalam penulisan paper ini terdapat beberapa langkah-langkah dalam menuliskannya. Langkah pertama yang dilakukan adalah melakukan formulasi permasalahan dengan cara memilih topic yang akan diangkat dan menuliskan permasalahan permasalahan apa saja yang dihadapi. Topik yang diangkat dalam paper ini adalah efisiensi energy pada jaringan seluler Setelah topik ditemukan maka selanjutnya dituliskan permasalahan apa saja yang dijumpai pada topik yang diangkat. Permasalahan yang ditemukan adalah komunikasi pada jaringan seluler menunjukkan peningkatan pada trafik data yang sangat signifikan sehingga menyebabkan tingginya konsumsi energi untuk memenuhi kebutuhan trafik data. Dalam mengurangi jumlah konsumsi energi pada jaringan seluler lima kategori pendekatan yang telah diklasifikasikan pada penelitian-penelitan sebelumnya, salah satunya adalah melalui teknik base station sleep mode. Dari hasil penulisan paper ini diharapkan mampu 
menyajikan sebuah informasi tentang seberapa besar tingkat efisiensi optimal yang dapat dicapai dengan teknik base station sleep mode pada jaringan seluler.

Langkah kedua pada penulisan paper ini adalah melakukan pengumpulan paper yang berkaitan dengan topik yang diambil. Pengumpulan paper ini dimulai dari mencari literatur yang relevan di internet di halaman IEEE dan Science Direct. Kata kunci yang digunakan dalam mendapatkan paper ini mengacu pada 3 nama, yaitu: cellular networking, green networking, dan Base-Stations Sleep-Mode. Setelah semua paper terkumpul maka selanjutnya dilakukan pemilahan terdapat paper. Pemilihan dilakukan dengan cara dikelompokkan berdasarkan 3 nama tersebut. Paper yang sudah dikelompokan selanjutnya dilakukan pemilahan kembali mana saja paper yang paling terkait dengan topik dan masalah yang diangkat. Pertanyaan yang digunakan untuk melakukan pemilahan adalah apakah paper yang ditemukan membahas cara dan hasil efisiensi energi dengan menggunakan teknik Base-Stations Sleep-Mode? Apabila tidak, maka paper yang telah didapat tidak digunakan.

Langkah ketiga pada penulisan paper ini adalah mengulas paper yang berhasil dipilah. Tahapan pertama yang dilakukan pada langkah ini adalah meringkas setiap paper yang ada. Ringkasan dilakukan dengan cara menemukan seberapa besar jumlah efisiensi energi pada jaringan seluler dengan teknik Base-Stations Sleep-Mode yang ada pada setiap paper. Tahapan kedua pada proses ini adalah memberikan pandangan terhadap paper. Pemberian pandangan terhadap paper ini pengambilan keputusan apakah paper yang diringkas disertakan dalam acuan penulisan paper ini atau tidak.

Langkah keempat adalah menganalisis dan mengiprestasikan paper. Pada langkah ini dilakukan proses penyajian data. Pada paper ini menyajikan data berupa jumlah pengurangan energi yang didapatkan pada jaringan seluler dengan teknik Base-Stations Sleep-Mode. Data ini disajikan dalam bentuk tabel dan diberikan pembahasan pada setiap nilai yang dihasilkan. Berdasarkan data ini akan didapatkan kesimpulan seberapa besar efisiensi optimal yang dapat dicapai dengan teknik BaseStations Sleep-Mode pada jaringan seluler.

\section{HASIL DAN PEMBAHASAN}

\subsection{Hasil}

Berdasarkan paper yang didapatkan dengan metode studi literatur seperti yang telah dijelaskan sebelumnya, jumlah paper yang didapat adalah sejumlah 30 paper yang membahas tentang green networking dan teknik BS Sleep-Mode serta paper yang berkaitan dengan topik mengurangi jumlah konsumsi energi pada jaringan seluler.Berdasarkan jumlah paper yang ditemukan dilakukan filtering terhadap paper sehingga menghasilkan 15 paper yang dijadikan acuan dalam penulisan paper ini.
Berdasarkan proses meringkas terhadap 10 paper yang dijadikan acuan, maka didapatkan beberapa poin penting, yaitu metode apa saja yang digunakan dalam menerapkan efisiensi energi dengan menggunakan teknik BS sleep-mode dan berapa besar pengurangan tingkat energi yang dihasilkan menggunakan teknik $B S$ sleep-mode dari beberapa macam teknik. Berikut merupakan penjabaran hasil dari tiga poin penting yang berhasil ditemukan:

\section{Pendekatan Metode}

Pada survey paper yang ditulis oleh Jingjin Wu

[2] disebutkan bahwa terdapat beberapa pendekatan yang dapat dilakukan dalam mengimplementasikan teknik BS Sleep-Mode pada jaringan seluler:

\section{a. User Association}

Pendekatan ini dilakukan dengan cara melibatkan end-user jaringan seluler dengan BS Sleep-Mode dalam efisiensi energi tanpa melibatkan BS Controller. Untuk memastikan QoS tidak berkurang secara signifikan ketika operasi BS Sleep-Mode, user yang pada awalnya terkoneksi pada BS yang akan masuk ke mode sleep akan dialihkan ke BS lain yang aktif.

\section{b. SON (Self-Organizing Network)}

Pendekatan ini diperkenalkan dalam standar 3GPP yang secara bertahap akan diimplementasikan pada BS bersamaan dengan standar 4G termasuk LTE dan WIMAX. SON menambahkan fitur pintar dan manajemen jaringan otomatis sehingga dapat mengurangi biaya, meningkatkan performa dan fleksibilitas dalam proses optimasi dan rekonfigurasi.

\section{c. Cell Zooming}

Cell zooming atau cell breathing adalah teknik pada network layer yang secara adaptif menyesuaikan cell size sesuai dengan kondisi trafik dengan menyesuaikan sudut kemiringan, tinggi, atau kekuatan transmit pada antena. Karena pada cell zooming jaringan yang memiliki cell coverage 0 sama saja dengan mematikan BS secara keseluruhan, maka metode ini dapat dikategorikan kedalam teknik BS Sleep-Mode.

\section{d. Traffic Prediction}

Pendekatan ini melakukan prediksi tren pada trafik di jaringan berdasarkan record sebelum-sebelumnya. pendekatan ini dilakukan dengan adaptasi terhadap perubahan pola trafik untuk mempertahankan akurasi dari perkiraan.

\section{e. Heterogenous Deployment}

Skema pada heterogenous deployment didesain untuk meningkatkan efisiensi jaringan seluler dengan pengurangan beban trafik dari macro cell tradisional ke micro cell yang lebih kecil sehingga akan meningkatkan jumlah 
penggunaan energi. Akan tetapi implementasi BS Sleep-Mode pada skema ini dapat memberikan performa lebih baik dalam efisiensi jika dibandingkan dengan cara tradisional yang hanya menggunakan macro cell. Pada waktu puncak trafik, sel-sel kecil yang lebih efisien dalam penggunaan energi digunakan utnuk menggantikan beberapa macro cell, lalu pada saat trafik lebih sedikit, maka sel-sel kecil tadi dirubah ke dalam mode sleep ketika macro cell dapat mempertahankan keluaran dan cakupan sesuai dengan standar QoS.

Selain pendekatan yang disebutkan pada paper yang ditulis oleh Jingjin Wu [2], Combes et al [7] juga membahas pendekan dengan metode Markov Decision Processes (MDPs). Pendekatan yang digunakan dengan kontrol optimal yang diasosiasikan dengan aktifasi kebijakan trafik/deaktifasi yang memaksimalkan fungsi dari Quality of Service (QoS) dan konsumsi energi. Pengggunaaan MDPs dengan menghitung probabilitas transisi, biaya, keuntungan dan nilai iterasi kemudian digunakan untuk memperoleh Kebijakan optimal.

\section{Hasil Implementasi Pendekatan}

Pada setiap pendekatan yang ditemukan, menunjukan nilai pengurangan energi yang dihasilkan dari penggunaan teknik BS Sleep-Mode terhadap penggunaan seluler. Data perbandingan nilai dari beberapa pendekatan tersebut dapat dilihat pada tabel 1 .

Tabel 1. Hasil implementasi pendekatan penggunaan teknik BS Sleep-Mode terhadap penggunaan seluler

\begin{tabular}{|l|l|l|}
\hline No & Pendekatan & \multicolumn{1}{|c|}{ Hasil } \\
\hline 1 & $\begin{array}{l}\text { User } \\
\text { Association }\end{array}$ & $\begin{array}{l}\text { Berdasarkan paper yang ditulis oleh } \\
\text { Kyuho Son [8] menunjukkan hasil } \\
\text { bahwa BS Sleep-mode melalui } \\
\text { pendekatan user association dapat } \\
\text { dilakukan. pendekatan ini } \\
\text { menghasilkan kesimpulan bahwa } \\
\text { secara dramatis dapat mengurangi } \\
\text { total energi pada selular sejumlah } \\
70 \text { s/d 80\% tergantung dengan } \\
\text { tingkat arrival pada trafict dan } \\
\text { kepadatan BS deployment. }\end{array}$ \\
\hline 2 & $\begin{array}{l}\text { SON } \\
\text { Organizing } \\
\text { Network })\end{array}$ & $\begin{array}{l}\text { model SON dengan algoritma yang } \\
\text { meniru imunitas dapat } \\
\text { meningkatkan performa jaringan } \\
\text { sekaligus mengurangi jumlah } \\
\text { penggunaan energi [14] }\end{array}$ \\
\hline 3 & $\begin{array}{l}\text { Cell Zooming } \\
\text { Berdasarkan paper yang ditulis oleh } \\
\text { Jyotbir [10] menunjukkan hasil } \\
\text { bahwa BS Sleep-mode melalui } \\
\text { pendekatan cell zooming telah } \\
\text { diemplementasikan pada real data } \\
\text { traffic. Pada penelitian tersebut } \\
\text { menunjukkan bahwa cukup banyak } \\
\text { penghematan energi diperoleh }\end{array}$ \\
\hline
\end{tabular}

\begin{tabular}{|l|l|l|}
\hline & & $\begin{array}{l}\text { dengan BS untuk beban lalu lintas } \\
\text { yang rendah. Pendekatan menurut } \\
\text { Balasubramaniam [11] penelitian } \\
\text { ini menunjukkan bahwa hampir } \\
\text { mencapai pengurangan 40\% dalam } \\
\text { konsumsi daya dapat dicapai pada } \\
\text { base station dengan cell zooming. }\end{array}$ \\
\hline 4 & $\begin{array}{l}\text { Traffic } \\
\text { Prediction }\end{array}$ & $\begin{array}{l}\text { Berdasarkan paper yang ditulis oleh } \\
\text { Simone [12] menunjukkan hasil } \\
\text { bahwa BS Sleep-mode melalui } \\
\text { pendekatan traffic prediction } \\
\text { disajikan dan dievaluasi untuk } \\
\text { penyebaran umum jaringan seluler } \\
\text { generasi kedua dan ketiga. } \\
\text { Penelitian ini menunjukkan } \\
\text { peningkatan yang signifikan dari } \\
\text { efisiensi energi selama periode lalu } \\
\text { lintas rendah sehubungan dengan } \\
\text { skenario biasa, berkat adopsi dari } \\
\text { strategi yang diusulkan. }\end{array}$ \\
\hline 5 & $\begin{array}{l}\text { Heterogenous } \\
\text { Deployment }\end{array}$ & $\begin{array}{l}\text { Berdasarkan paper yang ditulis oleh } \\
\text { Marco [13] penghematan energi } \\
\text { pada weekend di areal bisnis dapat } \\
\text { mencapai 90\% }\end{array}$ \\
\hline
\end{tabular}

\subsection{Pembahasan}

Fakta bahwa BS merupakan komponen yang paling memakan energi pada jaringan seluler membuat BS sleep-mode menjadi salah satu cara yang cukup ampuh dalam mengurangi konsumsi energi pada jaringan seluler. Banyak penelitian yang telah dilakukan dalam melakukan optimasi melalui BS Sleep-Mode dengan berbagai model dan pendekatan dalam rangka mengurangi jumlah konsumsi energi dengan tidak mengurangi standar kualitas layanan secara signifikan.

Salah satu penelitian yang dilakukan oleh Son dan lainnya [8], mereka mempelajari dynamic loadaware on/off operation pada base-station dimana BS pada umumnya beroperasi pada basis trafik tertinggi namun tetap beroperasi pada saat trafik sangat sepi tanpa memperhatikan kondisi trafik. Penelitian ini memecah permasalahan menjadi dua bagian: (1) energy efficient user association (2) energy efficient BS operation. Untuk masalah pada user association, mereka mengusulkan sebuah kebijakan energy efficient user association optimal dan menyajikan lebih lanjut implementasi didistribusikan dengan membuktikan konvergensi terlepas dari kondisi awal. sedangkan untuk energy efficient BS operation mereka mengusulkan algoritma sederhana greedy-on (GON) and greedyoff (GOFF) untuk mengatasi kompleksitas yang tidak diinginkan.

Dari hasil simulasi dengan konfigurasi praktis yang bervariasi, didapatkan kesimpulan bahwa user association policy dan algoritma pada BS operation yang diusulkan yang diusulkan dapat secara signifikan mengurangi konsumsi energi hingga 70$80 \%$, di mana jumlah penghematan energi tergantung pada tingkat trafik yang masuk dan distribusi spasial serta kepadatan penyebaran BS. 
Dalam penelitian lain, A. Özgür Umut dan C. Berk [14] mengusulkan sebuah algoritma yang terinspirasi dari sistem imun untuk autoconfiguration framework pada struktur self organizing network (SON) dimana pada pengujiannya jika dibandingkan dengan model $S M$ SON konsumsi energi yang digunakan bervariasi mulai dari $0 \mathrm{~mW}$ hingga $300 \mathrm{~mW}$ jika dibandingkan dengan model yang diusulkan dengan konsumsi energi sebesar $500 \mathrm{~mW}$ dengan perubahan naik-turun sebesar $50 \mathrm{~mW}$.

Hal ini membuktikan bahwa model yang diusulkan dalam penelitan [14] mampu menggunakan kapasitas jaringan lebih efisien dalam kondisi koneksi tinggi, namun pada tingkat penggunaan koneksi rendah penggunaan energi pada model SM-SON lebih rendah dari model yang diusulkan. Pada pengujian model yang diusulkan oleh A. Özgür Umut dan C. Berk [14] menunjukan bahwa pada model yang diusukkan pengurangan performa kritis setelah mode sleep diaktifkan hanya memiliki probabilitas 0.6 sehingga model tersebut dapat dikatakan mampu meningkatkan performa jaringan sekaligus melakukan efisiensi energi.

Dalam sebuah penelitian lain yang dilakukan pada heterogeneous deployment dengan studi kasus sebagian area pada kota Munich, Jerman dengan sleep-mode juga didapatkan nilai efisiensi energi hingga $90 \%$ pada akhir pekan di area bisnis dan perkantoran, dan $30 \%-40 \%$ pada kasus yang lain [9]. Beberapa paper lain [10][11] juga mendapatkan nilai efisiensi energi antara 20\%-40\% dengan menggunakan pendekatan cell zooming dan $26 \%$ $39 \%$ dengan pendekatan traffict prediction [12].

\section{KESIMPULAN}

\subsection{Kesimpulan}

Penggunaan base station yang paling banyak memakan energi tanpa melihat kondisi trafik akan menyebabkan pemborosan energi bisa membuat tingkat keuntungan sebuah operator jaringan berkurang. Dari Hasil Studi Literatur yang dibuat, penggunaan $B S$ Sleep-Mode dapat memenuhi efisiensi energi yang cukup tinggi dengan rata-rata 20\%-40\% pada hari kerja bahkan dapat mencapai $90 \%$ jika trafik sedang tidak banyak. Selain itu kemungkinan efisiensi dapat lebih tinggi jika $B S$ sleep-mode dikombinasikan dengan pendekatan lain dalam ranah green networking seperti smart-grid, renewable-energi, dan peningkatan efisiensi pada hardware.

\subsection{Saran}

Penelitan pada green networking untuk melakukan peningkatan efisiensi energi banyak banyak dilakukan dalam tahun-tahun belakangan ini. Sehatusnya masih lebih banyak yang bisa dieksplorasi dari penelitian-penelitian terakhir tentang BS Sleep-Mode dengan berbagai macam model implementasi dan pendekatnnya. Untuk penelitian selanjutnya dapat dilakukan perbandingan antara pendekatan-pendekatan dan bahkan model dalam melakukan implementasi teknik BS Sleep-Mode guna mendapatkan konfigurasi paling optimal pada berbagai macam kasus implementasi untuk jaringan seluler.

\section{DAFTAR PUSTAKA}

[1]. A. K. H. Y. M.-S. A. Hakim Ghazzai, "NextGeneration Environment-Aware Cellular Networks: Modern Green Techniques and Implementation Challenge," IEEEAccess, pp. 5010-5029, 2016.

[2]. J. Wu, Y. Zhang and M. Zukerman, "EnergyEfficient Base-Station Sleep-Mode Techniques in Gereen Cellular Networks: A Survey," IEEE Cummunication Surveys \& Tutorial, vol. 17, no. 2, pp. 803-825, 2015.

[3]. Y. Kang, S. Dong and J. Zhang, "An EnergyEfficient User Offloading Algorithm for Cellular Network in Base Station Sleep Mode," IEEE, 2016.

[4]. A. Ali and S. E. Elayoubi, "Design and performance evaluation of site sleep mode in LTE mobile networks," Proceedings of the 2014 26th International Teletraffic Congress (ITC), 2014.

[5]. R.V.R. Kumar and J.Gurugubelli, "How Green the LTE Technology Can Be?", Wireless VITAE 2011, Maret 2011.

[6]. Oh, Eunsung., Krishnamachari, Bhaskar., Liu, Xin., Niu, Zhisheng. 2011. "Toward Dynamic Energy-Efficient Operation of Cellular Network Infrastructure". IEEE Comunication

[7]. Combes, Richard., Elayoubi, Salah Eddine., Magazine, Juni 2011 Ali, Arshad., Saker, Louai, Chaced, Tijani. "Optimal online control for sleep mode in green base stations". Computer Networks, vol. 78, pp. 140-151, 2015.

[8]. Son, Kyuho, Kim Hongseok, Yung Yi. Bhaskar Krishnamachari, Magazine, September 2011. "Base Station Operation and User AssociationMechanisms for EnergyDelay Tradeoffs inGreen Cellular Networks". IEEE Journal on selected area in Communication Vol 29, No 8, 2011.

[9]. Son, Kyuho, Kim Hongseok, Yung Yi. Bhaskar Krishnamachari, Magazine, September 2011. "Base Station Operation and User Association Mechanisms for EnergyDelay Tradeoffs inGreen Cellular Networks". IEEE Journal on selected area in Communication Vol 29, No 8, 2011.

[10]. Jyotbir KaurLitt, Ameeta Seehra, Research Student,GNDEC,Ludhiana Punjab ,India. "Green Cellular Techniques for Energy Saving". Proc. of Int. Conf. on Advances in Signal Processing and Communication 2012.

[11]. R. Balasubramaniam, "Cell zooming techniques for power efficient base station 
operation," Master dissertation, Dept. Elect. Eng., San Diego State Univ., USA, 2012.

[12]. Simone morosi, Pierpaulo Piunti, Enrico Del Re. Emerging Telecommunication Thechnologies, February 2013. "Sleep mode management in cellular networks: a traffic based technique enabling energy saving". Wiley Online Library. Vol 24, Issue 3, 2013.

[13]. M. Marco Ajmone, L. Chiaraviglio, D. Ciullo, M. Meo, "On the effectiveness of single and multiple base station sleep modes in cellular networks," Computer Networks, vol. 57, pp. 3276-3290, 2013.

[14]. A. Özgür Umut, C. Berk, "Immune inspired green auto-configuration model for selforganizing networks", 2014 IEEE International Black Sea Conference on Communications and Networking.

[15]. E. Oh, B. Krishnamachari, X. Liu, and Z. Niu, "Towards dynamic energy-efficient operation of cellular network infrastructure," IEEE Commun. Mag., vol. 49, no. 6, pp. 56-61, June 2011. 